\title{
Effect Ownership, Accountant Public Office, and Financial Distress to the Public Company Financial
} Fraudulent Reporting in Indonesia

\author{
Ana Mardiana \\ Hasanuddin University, Makassar, Indonesia \\ ana_mardiana1902@yahoo.com
}

\begin{abstract}
This study empirically examine the influence of ownership, accountant public office and the financial distress on fraudulent financial reporting. The variables studied were foreign ownership, family ownership, accountant public office and the financial distress of public companies in Indonesia in 2009 to 2012. The research was conducted by quantitative methods using secondary data. Secondary data comes from a list of cases Bapepam-LK and the annual reports listed companies on the Stock Exchange. This population of study was company listed on the Stock Exchange, and then the samples were taken by purposive sampling criteria the company's corporate criteria sanctioned Bapepam-LK and the sanctions contained elements of fraud, including the non-financial corporate sector and have the data required in this study. At the end, the total sample of 64 companies that the company. This study uses logistic regression statistical tools as the dependent variable is a dummy variable (non-metric), while the independent variable is a variable mixture of metric and non-metric. The results show that the family ownership significantly affect financial reporting fraud but in the opposite direction because of the negative impact. Foreign ownership of a significant negative effect on fraudulent financial reporting. This indicates the greater ownership by the family, the lower the level of financial of fraudulent reporting accountant public office has no effect on fraudulent financial reporting. This occurs because both KAP Big Four and Small Firm have the same standards in Generally Accepted Accounting Principles (GAAP) in carrying out their duties as auditor. Financial distress negatively affects fraudulent financial reporting.
\end{abstract}

Keywords: Fraudulent financial reporting, ownership, accountant public office, and financial distress

\section{Introduction}

Background: The financial report is a mean to provide the necessary information as a basis for decision making by internal and external of companies. The information presented should be relevant and has reliability that information should be free from misleading understanding, material errors, and reliable wearer as sincere and honest presentation of which should be presented or that may reasonably be presented. Intal and Do (2002) stated that in the last two decades of financial statement fraud has increased substantially. Increased fraud in the financial statements on the one hand can be provide benefits for businesses because they can exaggerate the results of overstated and their financial circumstances so that their financial statements look good in the public, but the increase in fraud reports are also very adverse the public who depend on their decision based on the financial statements. The increasing variety of cases in the world of accounting scandals led to various parties speculates that management has done a fraud on the financial statements (Skousen and Wright, 2009). Accounting fraud scandal has grown in several countries, including in America. WorldCom, the second largest telecommunications company in the United States, admitted to the accounting scandal involving the CEO. Cases involving managerial in this case the CEO who commit acts of fraud are usually caused by the pressure of the company to gain as much as possible and be able to attract investors. CEOs who commit this fraud are influenced by the age of the CEO. Research conducted by Hambrick and Mason (1984) stated that the younger executives have a tendency to use a more risky strategy, "follies of youth".

Cases of fraudulent financial reporting are also influenced by ownership. Hasnan et al. (2008) managerial ownership can motivate companies to involve in fraudulent financial reporting. In particular, a company has a strong motivation to perform fraudulent financial reporting when the company was owned by the family and foreign ownership. Claessens et al. (1999) suggests the existence of expropriation significantly by shareholders controlled by the family, which will affect the accounting policies used appropriate with their interests. Research conducted by Chen et al. (2006) examined the accounting fraud in China by connecting cheating with variables, one of which is foreign ownership. Soselisa and Mukhlasin (2008) concluded that the auditor's opinion significant effect on fraudulent financial reporting. The involvement of the top ranked public accountant. Various cases of financial statement fraud committed by large corporations, is seen to fail to be prevented by a public accountant who audited the company, which has caused the public to question again whether public accountant actually able to deliver a quality audit services (Novianti and Irianto, 2012). However, the results of research by Soselisa and Mukhlasin (2008) found that the firm does not affect the type of fraudulent financial reporting. Similarly, research by Carcello (2004) found that the accountant public office BIG 4 not affect the tendency of fraudulent financial reporting. Financial distress also affects fraudulent financial reporting.

Bad financial condition motivates management to take action that is unethical to improve the appearance of the company's financial position. This is done so that the external companies assess the performance management success thus reduce the potential threat of losing their jobs. Results of research conducted by Hasnan et al. (2008) found that financial distress positive effect on fraudulent financial reporting. Based on the theory of fraud triangle, financial distress can be categorized as pressures faced by businesses related entities business; the circumstances motivate management to perform fraudulent financial reporting with the aim of showing the internal and external that the business entity is healthy and good performance despite its 
performance in critical condition. Increased fraudulent financial reporting profitable businesses on the one hand by overstated. The results of operations and financial condition so it looks good in the public, but on the other hand are very dependent perverse economic decisions of financial statement information. Financial information that is relevant and free from elements of fraud, will bear the economic decisions that are right for third parties that contain fraudulent information otherwise would be very misleading in the decisionmaking process. Companies are trying as hard as possible to produce financial statements that look good to increase the value of the company. This makes the company feel depressed and perform a variety of ways so that their financial statements look good, one through fraud in the financial statements. Fraud in the financial statements is very detrimental to investors, creditors, auditors and other interested parties on the company's financial statements. Based on the research and give different results, the researchers are interested to reexamine the effect of ownership, type of accountant public office and financial distress against fraudulent financial reporting.

Formulation of the problem: Based on the background described, the issues to be discussed in the study are formulated in the form of research questions are:

- Is family ownership affects fraudulent financial reporting.

- Is foreign ownership affected fraudulent financial reporting.

- What kind of accountant public office affects fraudulent financial reporting?

- Is the financial distress affecting the fraudulent financial reporting?

Research Purposes: The research objective to be achieved is as follows:

- To determine whether family ownership affects fraudulent financial reporting.

- To determine whether foreign ownership affect fraudulent financial reporting.

- To determine whether the type of accountant public office affect fraudulent financial reporting.

- To determine whether the financial distress affecting the fraudulent financial reporting.

\section{Literature Review}

Agency Theory: Agency theory (Jensen and Meckling, 1976) is often used to explain the accounting fraud. The main principle of this theory states that the organization as a cooperative relationship between the shareholders (principals) and manager (agent) based on the agreed contract. Research conducted Jensen and Meckling (1976) explains that the agency theory are agency problems that will occur when the proportion of top managers of the company's stock ownership is less than $100 \%$ so that managers tend to act to pursue the interests of himself and his own unfounded maximize value in making funding decisions. They explained that the manager does not bear the risk for errors in decision-making, and the risk is fully borne by the shareholders (principals). Therefore, the managers tend to do consumptive expenditure and unproductive for their own interests, such as an increase in salary and status.

Fraud: Black's Law Dictionary Fraud elaborate on the notion of fraud include all kinds that may be of men, and were pursued by a person for the benefit of another person with the suggestion that one or coercion truth and includes all manner of unexpected, full of tactics, cunning, hidden, and every dishonest ways that cause others to be fooled. In short it can be said that fraud is cheating (cheating) related to the amount of money or property (Simbolon, 2010). The ACFE (The Association of Certified Fraud Examiners) the Association of Certified Fraud Examiner domiciled in the United States, classify fraud within three (3) types or typologies of works, namely:

- Financial Statement Fraud. Financial Statement Fraud can be defined as the fraud committed by management in the form of material misstatement of financial statements.

- Asset Misappropriation. Misuse of asset can be classified into Cash Cheating and Fraud on inventories and other assets, as well as expenses fraudulent disbursement.

- Corruption: Corruption is a management behavior is unnatural and not legally enriches themselves or others by means of abusing the power given to them. According to the ACFE, corruption is divided into a conflict of interest, bribery, illegal gratuity, and economic extortion.

This study focuses on Financial statement fraud where the fraud committed by management.

\section{Figure 1: Fraud Triangle}

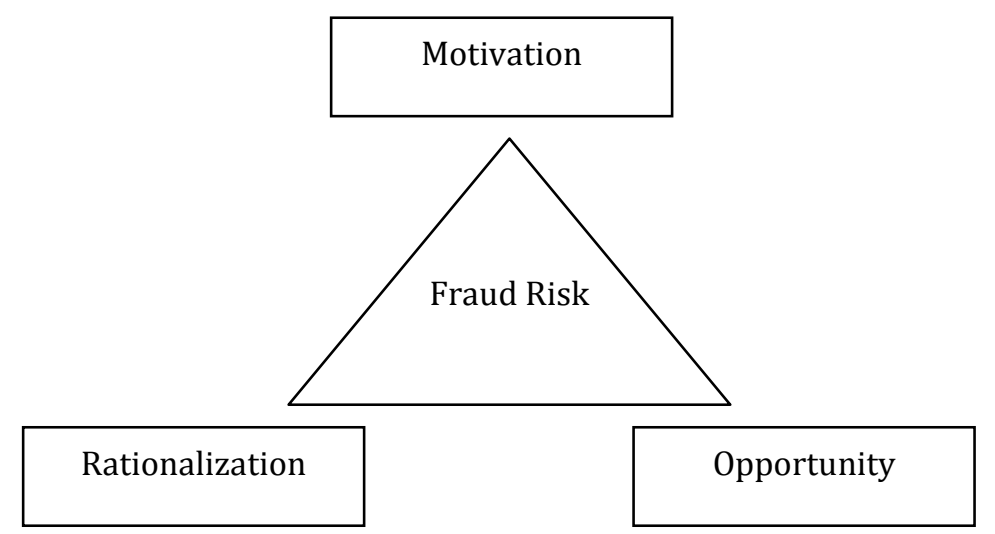

Triangular Theory of Fraud (Fraud Triangle Theory): The fraud triangle is a model to explain the factors that cause a person to commit occupational fraud. The fraud triangle comes from Donald Cressey. Additionally, objectivity may disappear or be reduced when there is a conflict of interest, emotional bonding, 
or other psychological bias (Sulistiawan and Yeni, 2011). The term triangular causes of fraud (fraud triangle) which consists of: (1) pressure or motivation to someone or individuals will make them look for opportunities commit fraud, a few examples of pressure may arise due to personal financial problems, vices such as gambling, drugs, Excessive debt and work deadlines and targets are unrealistic, (2) opportunity usually arise as a result of weak internal controls in the organization. The opening of this opportunity can also tempt individuals or groups who previously had no motive to commit fraud, (3) rationalization occurs because someone is looking for justification for its activities containing fraud (Sulistiawan and Yeni, 2011). These three factors are described in the fraud triangle following the (Simbolon, 2010):

Family Ownership: Morck and Yeung (2003) defines family ownership to include companies that only run by heirs who were previously responsible or by a family who clearly in the process of transferring control to the heirs. Many small businesses around the world are a family company. Small shop, carpentry shops, farms, and restaurants often become family ownership. Shareholding by the family or a group of people who still have relative's relationship is generally found in a family company that has been handed down for generations. Family company has a characteristic that generally has a pyramid structure that shows the relationship between the parent company (parent) and several subsidiaries (subsidiary) (Morck and Yeung, 2003).

Foreign Ownership: Foreign ownership is ownership of the shares owned by multinationals. Foreign ownership in the company is a party that is considered to be concerned about the disclosure of corporate social responsibility (Anggaraini, 2011). Foreign companies receive better training in accounting from the parent company abroad; foreign companies may have a more efficient information system to meet internal needs and the parent company as well as the possibility of a greater demand on foreign-based company from customers, suppliers, and communities general.

Audit: DeAngelo (1981) suggested that audit quality increases with the size of the firm because the firm has the ability to be great to specialize and innovate through technology that increases the likelihood of accountant public office great to find a breach in the company's accounting system. The existence of resources and comparative advantages possessed by the auditor with a large scale, then the auditor will be able to detect and correct errors of corporate financial reporting. Some previous literature found evidence that there was no significant difference between companies that commit fraud with the company does not commit fraud in audit quality as measured by accountant public office accountant public office BIG 4 versus non BIG 4 in the period before the financial detection.

Financial Distress: Conditions of financial hardship is defined as a condition in which the company's operating results are not sufficient to meet the obligations of the company (insolvency). Insolvency can be divided into 2 categories (Emery, Finnery, Stowe, 2004 in Candrawati, 2008), namely: (1) technical insolvency, and the emergence of temporary cash shortage because the company to meet short-term obligations, (2) bankruptcy insolvency, and the emergence of a more serious nature when the total value of the debt exceeds the value of the total assets of the company or the value of the company's equity is negative.

\section{Methodology}

Design Research: This study uses a quantitative approach because the data obtained in the form of figures and statistical analysis using. . The study hypothesis was developed based on theories that were tested based on data collected. This study is a cross-sectional study of one phase of a type for which data is in the form of several subjects at a given time (Indriantoro and Supomo, 1999).

Population and Sample: The study population was all public companies listed in Indonesia Stock Exchange in 2008-2012. Used year is the year 2008-2012 for the years before 2007, the existing data has not been well documented, whereas in 2012 the use of the data for the freshness of data. The sample selection is done by using purposive sampling method. The company is eligible to be used as samples in this study were as many as 64 companies.

\section{Table 1: sample selection for the study}

\begin{tabular}{llll}
\hline No & Industry & $\begin{array}{l}\text { Cheating } \\
\text { Company }\end{array}$ & $\begin{array}{l}\text { Company Not } \\
\text { Cheating }\end{array}$ \\
\hline 1 & Basic Industry And Chemicals & 6 & 6 \\
2 & Property, Real Estate And Building Construction & 10 & 10 \\
3 & Infrastructure, Utilities \& Transportation & 5 & 5 \\
4 & Trade, Services \& Investment & 7 & 7 \\
5 & Consumer Goods Industry & 1 & 1 \\
6 & Mining & 2 & 2 \\
7 & Agriculture & 1 & 1 \\
& Total & 32 & 32 \\
\hline
\end{tabular}

Data Collection Methods: In order to collect data for the purposes of this study researchers used secondary data consisting of indirect observation and literature conducted by searching data similar research has been done before, and from the literature relevant to this study. 
Operational Definition and Measurement: The variables in this study consisted of the dependent variable, independent variable. The dependent variable used is fraudulent financial reporting; the independent variable is the factor of ownership (family ownership and foreign ownership), the type of accountant public office, and financial distress.

\section{Requested Model}

Figure 2: Model Research

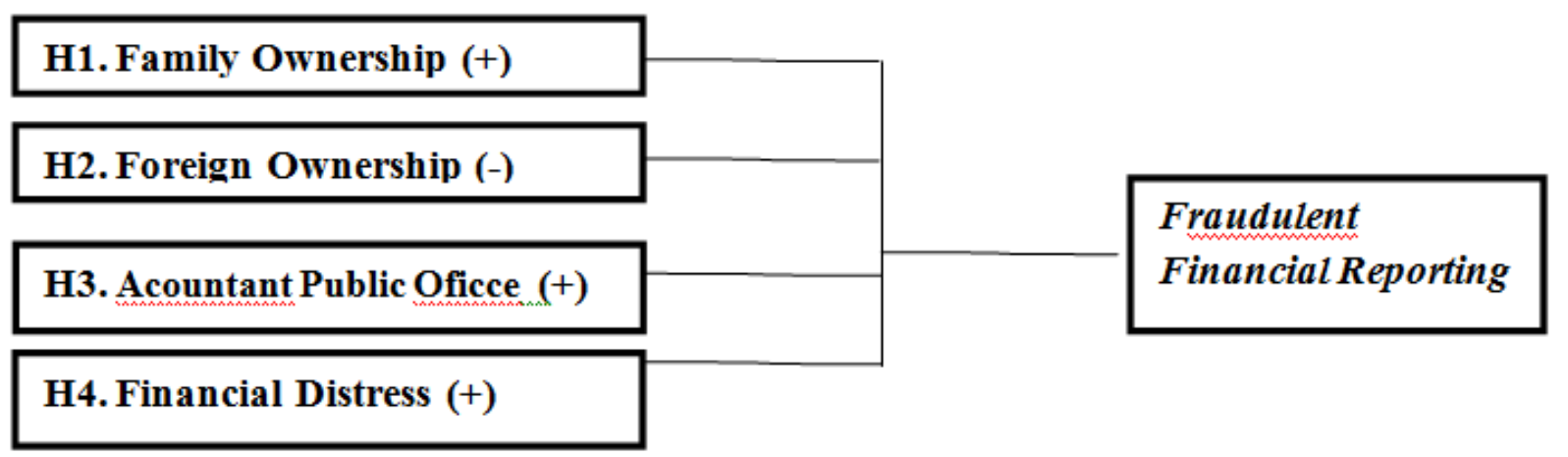

Family Ownership (FAMOWN): Family ownership is ownership by a family or a group of people who still have relatives relationship is generally found in a family company that has been passed down from generation to generation (Morck and Yeung, 2003). Family ownership variables measured by the percentage of family ownership in the ten largest shareholders, with a larger value indicates greater family interests in the company.

Foreign Ownership (FOREIGNOWN): Foreign ownership is ownership of the shares owned by multinationals. Foreign ownership in the company is a party that is considered to be concerned about the disclosure of corporate social responsibility (Anggaraini, 2011). Foreign ownership is the percentage of shares owned by foreign shareholders in the ten largest shareholders.

Type accountant public office: Big Four auditors (the Big Four Auditors) is a group of four professional services firm and the largest international accounting, which handles the majority of the audit work for a public company or private company (Reskino, 2002). Accountant public office type variable is a dummy variable that will be given a score of 0 for companies that use the firm belonging to the Big Four, and a value of 1 for the companies that use accountant public office are not included in the group of the Big Four.

Financial Distress: The financial company's trouble condition is defined as a condition in which the company's operating results are not sufficient to meet the obligations of the company (Insolvency). Variable financial distress (DISTRESS) was measured by using the Altman Z-Score (Altman, 1968) and a dummy variable which rated "1" if the following Altman Z-Score values $(<2.99)$ and the value " 0 " if not. The Altman Z-Score formula of the following:

$\mathrm{Z}=6.56 \times 3.26 \mathrm{X}_{1}+{ }_{2}+{ }_{3}+6.72 \times 1.05 \mathrm{X}_{4}$

Where:

$\mathrm{X}_{1}=$ Working Capital to Total Assets

$\mathrm{X}_{2}=$ Retained Earnings to Total Assets

$\mathrm{X}_{3}=$ Earnings before Interest and Taxes to Total Assets

$\mathrm{X}_{4}=$ Market Value of Equity to Total Liabilities

Financial Reporting Fraud: Fraudulent financial reporting is a fraud on the financial statements that include actions willful misconduct on certain financial value to produce a better profit view to deceive or mislead shareholders and creditors (Nurharyanto, 2011). Variable fraudulent financial reporting (FFR) is measured by giving the value " 1 " if the company is doing fraudulent financial reporting and the value " 0 " if the company did not commit fraud. Classification of companies that perform fraudulent financial reporting based on case reports issued by Bapepam-LK from 2008 until 2012, regarding public enterprises given sanction for committing fraudulent financial reporting.

Data Analysis Techniques: Testing of the hypothesis in this study using logistic regression to determine the effect of family ownership, foreign ownership, type of accountant public office and financial distress against fraudulent financial reporting. Calculations using the tool SPSS as a basis for analyzing to prove the proposed hypothesis. The logistic regression equation is as follows:

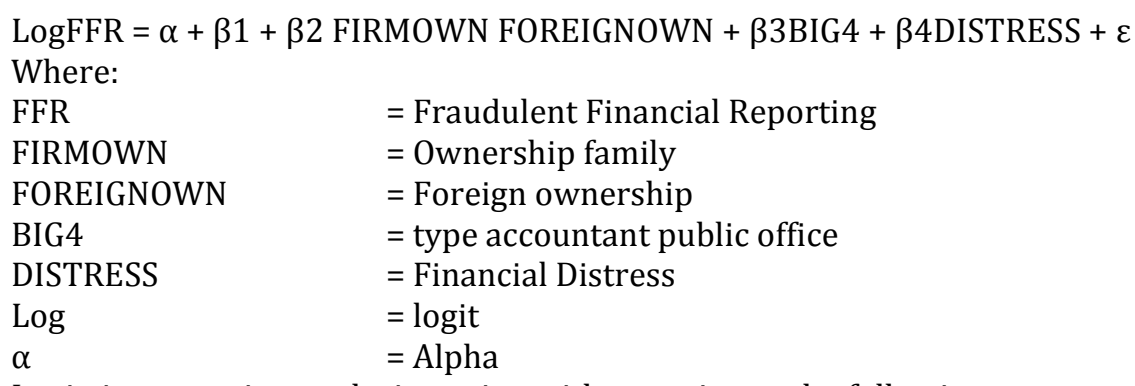


Assess the feasibility of the regression model (quality data test): Examine the output of Hosmer and Lemeshow's Goodness of Fit Test, the hypothesis:

$\mathrm{H}_{0}$ : the hypothesized model fit to the data

$\mathrm{H}_{\mathrm{a}}$ the hypothesized model does not fit with the data

As a basis for a decision, consider the value of goodness of fit test as measured by Chi-Square at the bottom of the Hosmer and Lemeshow test:

a. If the probability of $>0.05$ then ${ }_{\text {но }}$ is accepted and $\mathrm{H}_{\text {a }}$ rejected

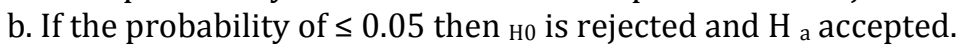

Assess the overall model (overall model fit): Testing is done by comparing the -2 Log Likelihood (-2LogL) at the start (Block Number $=0$ ) and the numbers -2 Log Likelihood at the end (Block Number $=1$ ). If a decline in the numbers -2 Log Likelihood (Block Number 0 - Block Number 1) showed a good regression model. Log Likelihood value on logistic regression is similar to the definition of "sum squared error" in the regression model, so the decline in Log Likelihood showed a good regression models.

Assess the variability of the dependent variable: To assess the variability of the dependent variable that can be explained by the variability of the independent variable, can be seen from the value of Cox and Snell's R Square. Cox and Snell's R Square is a measure that seeks to imitate the size of R2 in multiple regression based on estimation techniques likelihood with a maximum value of less than 1 (one) so it is difficult to interpret. Nagelkerke R Square is a modification of the coefficient Cox and Snell to ensure that its value varies from 0 (zero) to 1 (one).

\section{Results}

Description of Data: This study used a population of companies listed on the Indonesia Stock Exchange from 2008-2012. To sample using the number of companies registered in the list of cases over the years 20082012 issued by Bapepam LK for committing fraud in financial reporting as many as 46 companies. Of the 46 companies, a total of 44 non-financial companies is company and two companies are financial companies.

\section{Description of Result}

Hosmer and Lemeshow's Goodness of Fit Test: Based on test results Hosmer and Lemeshow's Goodness of Fit Test showed bahwa sebesar 0.5317 .053 with a significance probability that they are above 0.05 . Thus it can be concluded that the model is acceptable because it fits with the data observations so as to predict the value of observation.

\section{Table 2: Hosmer and Lemeshow's Goodness of Fit Test}

\begin{tabular}{llll}
\hline Step & Chi-square & Df & Sig. \\
\hline 1 & 7053 & 8 & .531 \\
\hline Source: & Secondary data
\end{tabular}

Source: Secondary data were processed, 2014

Cox and Snell's R Square and Nagelkerke R Square: Based on the results of testing the value of Cox and Snell's R Square of 0.240 and the value Nagelkerke R Square of 0.320 which means that the dependent variable that can be explained by $32 \%$, while the remaining $68 \%$ is explained by other variables outside the model.

Table 3: Cox and Snell's R Square and Nagelkerke R Square

\begin{tabular}{llll}
\hline Step & $\mathbf{- 2}$ Log likelihood & Cox \& Snell R Square & Nagelkerke R Square \\
\hline 1 & $71155^{\text {a }}$ & .240 & .320 \\
\hline
\end{tabular}

Source: Secondary data were processed, 2014

Table Classification: Based on the test results show that the classification table in the column that is predictive of a company that does fraudulent financial reporting, there are 32 , while the line is the result of actual observation perform fraudulent financial reporting that 24 companies, so the accuracy of this model is $24 / 32$, or at $68.75 \%$

Table 4: Cox and Snell's R Square and Nagelkerke R Square

\begin{tabular}{llllll}
\hline & & \multicolumn{3}{c}{$\begin{array}{l}\text { Predicted } \\
\text { Fraud }\end{array}$} & $\begin{array}{l}\text { Percentage } \\
\text { Correct }\end{array}$ \\
\hline Step 1 & Fbserved & $\mathbf{0}$ & $\mathbf{1}$ & 75.0 \\
& & 0 & 24 & 8 & 75.0 \\
& 1 & 8 & 24 & 75.0 \\
\hline
\end{tabular}

Source: Secondary data were processed, 2014 
Table 5: Logistic Regression Results

\begin{tabular}{lllll}
\hline Variables & $\begin{array}{l}\text { Predicted } \\
\text { Direction }\end{array}$ & $\begin{array}{l}\text { Number } \\
\text { Hypothesis }\end{array}$ & Coefficient & Significance \\
& + & 1 & -4.696 & 0,018 \\
\hline Family & - & 2 & -2.850 & 0,013 \\
Foreign & - & 3 & -0.326 & 0,624 \\
Type Big 4 & + & 4 & -1.526 & 0,029 \\
Distress & + & &
\end{tabular}

Source: Secondary data were processed, 2013

Based on the hypothesis test show that the independent variables independent variables of family ownership negatively affect fraudulent financial reporting. This can be seen from the significance value of 0.018 which is less than 0.05 with a coefficient of -4.696 . The independent variables of foreign ownership negative effect on fraudulent financial reporting. This can be seen from the significance value of 0.013 which is less than 0.05 with a coefficient of -2.850 . The independent variable does not affect the type of KAP fraudulent financial reporting. This can be seen from the significance value of 0.624 with a coefficient of -0.326 . The independent variable of financial distress negatively affects the financial reporting fraud. This can be seen from the significance value of 0.029 which is less than 0.05 with a coefficient -1.526 .

Discussion: This study shows that family ownership, foreign ownership and financial distress affect the fraudulent financial reporting. It means that the increase in fraudulent financial reporting in besides, profitable businesses with overstated the results of operations and financial condition so it looks good in the public, but on the other hand are very dependent perverse economic decisions of financial statement information. Family ownership significantly affect financial reporting fraud but in the opposite direction because of the negative impact. This indicates the greater ownership by the family, the lower the level of fraudulent financial reporting. This is because the concentration of ownership by the family can put shareholders actively to promote quality presentation of financial statements, because they can freely monitor and discipline managers.

Foreign ownership of a significant negative effect on the fraudulent financial reporting. This indicates the greater ownership by the family, the lower the level of fraudulent financial reporting. This is because foreign ownership would encourage companies to implement corporate governance standards are higher and the protection of minority shareholders better so that companies with foreign ownership will be less likely to commit fraudulent financial reporting. Accountant public office type has no effect on fraudulent financial reporting. This occurs because both accountant public office Big Four and Small Firm have the same standards in Generally Accepted Accounting Standards (GAAS) in carrying out their duties as auditor. Accountant public office both large and small has more ability to specialize and innovate through technology that increases of accountant public office large and small to find a breach in the company's accounting system. Financial distress negatively affects financial reporting fraud. This is because a bad financial condition motivates management to take action that is unethical to improve the appearance of the company's financial position. This is done so that the external companies assess the performance management success thus reduce the potential threat of losing their jobs.

\section{Conclusion and Recommendations}

The purpose of this study to examine the foreign ownership, family ownership, type of accountant public office and financial distress of the fraudulent financial reporting. From the research that has concluded that:

- Family Ownership negatively affects financial reporting fraud. This is because the more the families, who hold shares of the company, are likely to take a decision in accordance with shareholder welfare. The shareholders would want a company that has a high return rate that can provide big dividends. The shareholders of the company that wants to invest continue to be sustainable place in the future. Shareholders likely to want the company to comply with the rules (no cheating) for the continuation of the company.

- Foreign Ownership significant effect on fraudulent financial reporting. These results indicate that foreign ownership would encourage companies to implement corporate governance standards are higher and the protection of minority shareholders better so that companies with foreign ownership would be less likely to commit fraud.

- Type accountant public office no significant effect on fraudulent financial reporting. Based on attribution theory, external factors in the case of fraudulent financial reporting comes from the firm that provides audit services. In this case means the firm refused to help and collaborate with clients to manipulate the company's financial statements. The presence of accountant public office will weaken / minimize fraud on a company's financial reporting.

- Financial distress negatively affects financial reporting fraud. This is because a bad financial condition motivates management to take action that is unethical to improve the appearance of the company's financial position.

Recommendations: Based on the conclusion, these recommendations can be given is:

- Future studies should include a sample of the company's fraudulent financial reporting reproduced and longer study period, so as to obtain a more comprehensive results of the research conducted.

- Future studies could use the variables that are included in the financial factor in testing the effects on fraudulent financial reporting of public companies in Indonesia such as financial ratios and profitability levels 


\section{References}

Anggraini, R. (2011). Pengaruh Kepemilikan Institusional dan Kepemilikan Asing Terhadap Pengungkapan Pertanggungjawaban Sosial Perusahaan dalam Annual Report. Skripsi. Universitas Dipongero. Semarang

Altman, E. (1968). Financial Ratios, Discriminant Analysis and the Prediction of Corporate Bankruptcy. Journal of Finance, 2, 589-609

Candrawati, A. (2008). Analisis Faktor-Faktor yang Mempengaruhi Keberhasilan Turnround Pada Perusahaan yang Mengalami Financial Distress. Thesis. Universitas Diponegoro. Semarang

Carcello, J. V. (2004). Audit Firm Tenure and Fraudulent Financial Reporting. University of Missouri's. United States of America.

Chen, L., Yue, M. \& Dongwei, S. (2006). Corporate Governance and Firm Efficiency: Evidence from China's Publicly Listed Firms. Institute of Humanities and Social Sciences at Universities and the Innovative Research Team Project of Jinan University

De Angelo, L. E. (1981). Auditor Size and Audit Quality. Journal of Accounting \& Economics, 3(1).

Hambrick \& Mason. (1984). Upper Echelons: The Organization as a Reflection of Its Top Managers. The Academy of Management Review, 9(2).

Hasnan, S., Rashidah, A. R. \& Mahenthiran, S. (2008). Management Predisposition, Motive, Opportunity, and Earning Management for Fraudulent Financial Reporting in Malaysia.

Indriantoro, N. \& Supomo, B. (1999). Metodologi Penelitian Bisnis. BPFE-Yogyakarta.

Intal, T. \& Do, L. (2002). Recognition of Revenue and the Auditor's Responsibility for Detecting Financial Statement Fraud. Accounting and Financial. Master Thesis, No.2002:53

Jensen, M. C. \& Meckling, W. H. (1976). Theory of the Firm: Managerial Behavior, Agency Costs and Ownership Structure. Journal of Financial Economics, 3(3).

Morck, R. \& Young, B. (2003). Special Issues Relating To Corporate Governance and Family Control. Global Corporate Governance Forum

Nurharyanto. (2011). Memahami Fraud dan Melaksanakan Investigative Audit Pada Perusahaan /Korporasi (Teori dan Aplikasinya). Lembaga Pengembangan Fraud Auditing

Novianti, S. \& Irianto, G. (2012). Tenur Akuntan Publik, Tenur Partner Audit, Auditor Spesialisasi Industri, dan Kualitas Audit. Makalah. Simposium Nasional Akuntansi. Universitas Brawijaya. Surabaya

Simbolon, A. H. (2010). Mengupas Seluk Beluk Fraud dan Cara mengatasinya. Akuntansi Bisnis

Sulistiawan \& Yeni, J. (2011). Creative Accounting. Jakarta: Salemba Empat

Skousen, J. C. \& Wright, J. C. (2009). Detecting and Predicting Financial Statement Fraud: The Effectiveness of The Fraud Triangle and SAS No. 99. Advances in Financial Economics, 13(2).

Soselisa, R. \& Mukhlasin, L. (2008). Pengaruh Faktor Kultur Organisasi, Manajemen, Strategik Keuangan, dan Auditor terhadap Kecenderungan Kecurangan Akuntansi Pada Perusahaan Publik di Indonesia. Thesis. Unika Atma Jaya Jakarta.

Reskino. (2002). Profesi Akuntan Publik. Makalah. Pusat Pengembangan Bahan Ajar. Universitas Mercu Buana. 